\title{
IMPLEMENTASI PERLUASAN KEWENANGAN PERADILAN TATA USAHA NEGARA BERDASARKAN UNDANG-UNDANG NOMOR 30 TAHUN 2014 DI PENGADILAN TATA USAHA NEGARA JAMBI
}

\author{
Herma Yanti * \\ Masriyani $^{*}$
}

\begin{abstract}
ABSTRAK
Lahirnya Undang-Undang Nomor 30 Tahun 2014 tentang Administrasi Pemerintahan teah memperluas kewenangan Peradilan Tata Usaha Negara dibandingkan sebelumnya berdasarkan UU Nomor 5 Tahun 1986 jo UU Nomor 9 tahun 2004 jo UU Nomor 51 Tahun 2009 tentang Peradilan Tata Usaha Negara. Perluasan kewenangan PTUN tersebut terkait dengan diperluasnya makna keputusan yang menjadi objek sengketa di PTUN serta penambahan kewenangan baru yaitu kewenangan mengadili tindakan pemerintahan, kewenangan pengujian ada tidaknya penyalahgunaan wewenang, kewenangan memutus permohonan atas keputusan fiktif positif, serta adanya pengalihan kewenangan memutus perkara pasca upaya administratif yang sebelumnya merupakan kewenangan Pengadilan Tinggi Tata Usaha Negara menjadi kewenangan Pengadilan Tata Usaha Negara Tingkat Pertama. Penelitian ini bertujuan mendeskripsikan lebih lanjut cakupan perluasan kewenangan PTUN berdasarkan UU Nomor 30 Tahun 2014 tersebut serta melihat implementasinya pada PTUN Jambi. Data-data penelitian ini terdiri dari data primer dan sekunder. Pengumpulan data dilakukan melalui studi dokumen dan wawancara terstruktur dengan responden di PTUN Jambi. Analisis data dilakukan secara kualitatif. Dari data-data tentang penanganan perkara yang dilakukan PTUN Jambi sejak Tahun 2015 hingga pertengahan Tahun 2019, belum semua kewenangan tersebut terlihat implementasinya pada PTUN Jambi.
\end{abstract}

Kata Kunci : Implementasi, Perluasan Kewenangan PTUN, UU Nomor 30 tahun 2014

\section{A. Pendahuluan}

Keberadaan Peradilan Tata Usaha Negara merupakan salah satu unsur penting dalam negara hukum. Hal ini terlihat pendapat F.J. Sthall bahwa negara hukum formal harus memenuhi empat unsur, yaitu :

1. adanya jaminan perlindungan hak asasi manusia

2. adanya pemisahan atau pembagian kekuasaan

3. pemerintah berdasarkan undang-undang

4. adanya peradilan tata usaha negara. ${ }^{1}$

Sebagai Negara hukum, negara Indonesia telah membentuk Pengadilan Tata Usaha Negara (PTUN) dengan diundangkannya Undang-Undang Nomor 5 Tahun 1986 tentang

\footnotetext{
* Pengajar Fakultas Hukum Unbari.

* Pengajar Fakultas Hukum Unbari.

${ }^{1}$ Rozali Adullah, Hukum Acara Peradilan Tata Usaha Negara, Rajawali Pers, Jakarta, 1992, hal.9
} 
Peradilan Tata Usaha Negara (selajutnya disingkat UU Peratun). Pembentukan PTUN ini bertujuan untuk memberikan perlindungan hukum bagi warga atas tindakan badan/pejabat tata usaha negara yang melawan hukum, merugikan dan memberikan perlindungan hukum bagi badan/pejabat tata usaha negara sendiri yang bertindak benar sesuai dengan hukum serta melakukan pengawasan (control) terhadap tindakan-tindakan badan/pejabat tata usaha negara, baik secara preventif maupun represif. Dengan demikian akan terjaga dan terwujud keserasian, keseimbangan, dan keselarasan antara kepentingan individu dengan kepentingan masyarakat. ${ }^{2}$

Sejak dibentuk berdasarkan Undang-Undang Nomor 5 Tahun 1986 yang kemudian diubah pertama kalinya dengan Undang-Undang Nomor 9 Tahun 2004 perubahan kedua dengan Undang-Undang Nomor 51 Tahun 2009 tentang Peradilan Tata Usaha Negara, PTUN mempunyai kewenangan menyelesaikan sengketa yang disebut dengan sengketa tata usaha negara. Kewenangan ini hanya terbatas pada penyelesaian sengketa yang timbul akibat dikeluarkannya Keputusan Tata Usaha Negara tertentu sebagaimana dirumuskan dalam Pasal 1 angka 3 yaitu berupa " penetapan tertulis yang dikeluarkan oleh Badan atau Pejabat Tata Usaha Negara yang berisi tindakan hukum Tata Usaha Negara berdasarkan peraturan perundang-undangan yang berlaku bersifat kongkrit, individual dan final, yang menimbulkan akibat hukum bagi seseorang atau badan hukum perdata". Adapun kewenangan lainnya yaitu mengadili objek sengketa berdasarkan Pasal 3, yaitu dalam hal Badan/Pejabat Tata Usaha Negara tidak menanggapi permohonan yang ditujukan kepadanya sampai batas waktu yang ditentukan atau setelah 4 bulan (jika jangka waktunya tidak ditentukan) sejak permohonan diterima sedangkan hal tersebut merupakan kewajiban dari pejabat yang bersangkutan, hal ini dianggap telah mengeluarkan keputusan yang menolak permohonan (dikenal dengan istilah keputusan fiktif negatif). Terhadap keputusan fiktif negatif ini dapat diajukan gugatan melalui PTUN agar pejabat yang bersangkutan menerbitkan keputusan yang dimohonkan.

Lahirnya Undang-Undang Nomor 30 Tahun 2014 tentang Administrasi Pemerintahan yang diundangkan pada Tanggal 17 Oktober 2014 membawa perubahan yang signifikan terhadap kewenangan PTUN. Dari ketentuan yang tersebar dalam pasalpasalnya, kewenangan PTUN diperluas. Perluasan kewenangan tersebut terkait dengan diperluasnya makna keputusan yang menjadi objek sengketa di PTUN serta penambahan

${ }^{2}$ https://legalitas.unbari.ac.id. Diakses Tanggal 23 Mei 2019 
kewenangan baru berupa kewenangan mengadili tindakan pemerintahan, kewenangan pengujian ada tidaknya penyalahgunaan wewenang, kewenangan memutus permohonan atas keputusan fiktif positif, serta adanya pengalihan kewenangan memutus perkara pasca upaya administratif yang sebelumnya merupakan kewenangan Pengadilan Tinggi Tata Usaha Negara menjadi kewenangan Pengadilan Tata Usaha Negara Tingkat Pertama.

Hal ini tentunya membuka ruang yang lebih besar bagi pencari keadilan untuk mengajukan perkara-perkara yang dihadapi sehubungan dengan adanya tindakan pemerintahan yang dianggap merugikan, sekaligus dapat meningkatkan eksistensi PTUN sesuai dengan tujuan pembentukannya yaitu memberikan perlindungan hukum bagi masyarakat terhadap sikap tindak pejabat pemerintahan sekaligus pengawasan terhadap tindakan-tindakan pejabat pemerintahan yang merugikan.

Setelah beberapa tahun UU Nomor 30 Tahun 2014 ini diundangkan, semestinya perluasan kewenangan tersebut telah dapat dilihat implementasinya, khususnya pada PTUN Jambi yang wilayah kewenangannya meliputi seluruh wilayah daerah di propinsi Jambi. Hal ini tentunya berkaitan erat dengan adanya perkara-perkara yang diajukan oleh para pencari keadilan ke PTUN Jambi. Berdasarkan uraian di atas, tulisan ini bermaksud membahas lebih lanjut tentang cakupan perluasan kewenangan PTUN berdasarkan UU Nomor 30 Tahun 2014 tentang Administrasi Pemerintahan dan implementasi dari perluasan kewenangan tersebut pada PTUN Jambi.

\section{B. Kerangka Teori}

Kewenangan berasal dari kata dasar wewenang. Menurut H.D. Stourt yang dikutip oleh Aminuddin Ilmar, wewenang merupakan suatu pengertian yang berasal dari hukum organisasi pemerintahan, yang dapat dijelaskan sebagai keseluruhan aturan-aturan yang berkenaan dengan perolehan dan penggunaan wewenang pemerintahan oleh subjek hukum publik di dalam hubungan hukum publik. ${ }^{3}$ Senada dengan pendapat tersebut, Marbun menjelaskan bahwa kewenangan (authority, gezag) adalah kekuasaan yang diformalkan baik terhadap segolongan orang tertentu, maupun kekuasaan terhadap sesuatu bidang pemerintahan tertentu secara bulat yang berasal dari kekuasaan legislatif maupun kekuasaan pemerintah. Selanjutnya dijelaskan bahwa wewenang adalah kemampuan untuk melakukan suatu tindakan hukum publik atau secara yuridis wewenang adalah kemampuan

\footnotetext{
${ }^{3}$ Aminuddin Ilmar, Hukum Tata Pemerintahan, Prenadamedia Group, Jakarta, 2014, hal.103
} 
bertindak yang diberikan oleh undang-undang yang berlaku untuk melakukan hubunganhubungan hukum. ${ }^{4}$

Dalam konsepsi negara hukum, wewenang pemerintahan itu berasal dari peraturan perundang-undangan. Sebagaimana dinyatakan oleh R.J.H.M Huisman yang dikutip dalam Ridwan HR bahwa “ Kewenangan hanya diberikan oleh undang-undang. Pembuat undangundang dapat memberikan wewenang pemerintahan tidak hanya kepada organ pemerintahan, tetapi juga terhadap para pegawai atau terhadap badan khusus seperti pengadilan atau bahkan terhadap badan hukum privat. ${ }^{5}$ Dalam hal ini yang dimaksud adalah kewenangan yang diberikan kepada pengadilan tata usaha negara dalam menyelesaikan sengketa yang menjadi kewenangannya.

Sebagaimana diketahui bahwa kewenangan (kompetensi) pengadilan terdiri atas kompetensi relatif dan kompetensi absolut. Kompetensi relatif adalah kewenangan pengadilan untuk mengadili suatu perkara sesuai dengan wilayah hukumnya. Sedangkan kompetensi absolut adalah kewenangan pengadilan sesuai dengan objek atau materi atau pokok sengketanya.

Kewenangan absolut PTUN yang semula berdasarkan UU Peratun hanya terkait dengan objek sengketa berupa keputusan tata usaha negara dengan lingkup yang sempit, dengan lahirnya UU Nomor 30 Tahun 2014 tentang Administrasi Pemerintahan, kewenangan PTUN tersebut menjadi lebih luas. Dengan kewenangan yang lebih luas tersebut, membuka ruang yang lebih besar bagi masyarakat untuk mengajukan perkaraperkara yang dihadapinya guna mendapatkan penyelesaian di PTUN sekaligus sebagai sarana mendapatkan perlindungan hukum dari perbuatan-perbuatan pemerintah yang melanggar hukum sesuai dengan tujuan dibentuknya PTUN. Melalui penyelesaian perkara yang diajukan tersebut akan terlihat adanya implementasi dari perluasan kewenangan yang dimiliki PTUN berdasarkan UU Nomor 30 Tahun 2014 tentang Administrasi Pemerintahan khususnya pada PTUN Jambi.

\section{Metode Penelitian}

Penelitian ini merupakan penelitian hukum empiris, yaitu menelaah norma-norma terkait dengan perluasan kewenangan Peradilan Tata Usaha Negara berdasarkan UndangUndang Nomor 30 Tahun 2014 tentang Administrasi Pemerintahan serta melihat

${ }^{4}$ Marbun, Peradilan Adminsitrasi dan Upaya Administrasi di Indonesia, UII Press, Yogyakarta,2003,hal.226

${ }^{5}$ Ridwan HR, Hukum Administrasi Negara, PT. Raja Grafindo Persada, Jakarta, 2007, hal.103 
implementasinya di PTUN Jambi. Sumber data terdiri dari data sekunder dan data primer. Data sekunder diperoleh melalui peraturan perundang-undangan, serta literatur berupa buku-buku, dokumen maupun artikel dan data primer yang diperoleh melalui wawancara dengan dua orang responden yang relevan dengan masalah yang diteliti pada PTUN Jambi. Data dianalisa secara kualitatif dan selanjutnya diambil kesimpulan sesuai permasalahan yang dikemukakan.

\section{Pembahasan}

1. Perluasan Kewenangan Peradilan Tata Usaha Negara Berdasarkan Undang-Undang Nomor 30 Tahun 2014 tentang Administrasi Pemerintahan.

Undang-Undang Nomor 30 Tahun 2014 tentang Administrasi Pemerintahan merupakan undang-undang umum di bidang hukum administrasi negara yang menjadi landasan dan pedoman bagi Badan dan/atau Pejabat Pemerintahan dalam penyelenggaraan tugas-tugas pemerintahan yang sangat luas sekaligus memuat pengaturan tentang perlindungan hukum bagi masyarakat dari sikap tindak Badan dan/atau Pejabat Tata Usaha Negara yang tidak sesuai dengan aturan hukum maupun prinsip-prinsip umum pemerintahan yang baik. Sebagai undang-undang umum, maka undang-undang dapat dikatakan sebagai hukum materil dari Sistem Peradilan Tata Usaha Negara yang sebelumnya belum ada.

Sebagaimana diuraikan sebelumnya bahwa lahirnya Undang-Undang Nomor 30 Tahun 2014 tentang Administrasi Pemerintahan telah memperluas kewenangan Peradilan Tata Usaha Negara, dengan diperluasnya objek sengketa yang dapat diajukan penyelesaiannya ke PTUN. Perluasan objek sengketa yang dapat diadili PTUN tersebut sekaligus juga memperluas subjek (pihak pihak) yang dapat mengajukan permohonan/gugatan ke PTUN.

Meskipun demikian, menurut Laica Marzuki, bahwa pemberlakuan UndangUndang Nomor 30 Tahun 2014 tentang Administrasi Pemerintahan ini tidak menyampingkan Undang-Undang Nomor 5 tahun 1986 tentang Peradilan Tata Usaha Negara sebagaimana diubah dengan Undang-Undang Nomor 9 Tahun 2009 dan terakhir dengan Undang-Undang Nomor 51 Tahun 2009. Secara mutatis mutandis, hanya saja perlu 
diadakan penyesuaian terhadap UU Nomor 30 Tahun 2014 sepanjang berkaitan dengan kekhususan prosedural daripadanya. ${ }^{6}$

Perluasan objek sengketa yang menjadi kewenangan PTUN ini tercermin dari beberapa substansi pasal-pasal Undang-Undang Nomor 30 Tahun 2014 ini. Adapun perluasan kewenangan tersebut menyangkut hal-hal berikut :

2. Perluasan Terhadap Makna Keputusan Tata Usaha Negara yang Menjadi Objek Sengketa.

Telah dijelaskan sebelumnya bahwa berdasarkan UU Peratun, kewenangan PTUN hanya terkait dengan objek sengketa berupa Keputusan Tata Usaha Negara tertentu yang cakupannya terbatas. Hal tersebut didasarkan atas rumusan Keputusan berdasarkan Pasal 1 angka 3 UU Nomor 5 Tahun 1986 yaitu "penetapan tertulis yang dikeluarkan oleh badan/pejabat tata usaha negara yang berisi tindakan hukum tata usaha negara yang bersifat konkrit, individual, dan final yang menimbulkan akibat hukum bagi seseorang atau badan hukum perdata". Dari rumusan tersebut tergambar sejumlah unsur/batasan-batasan yang mempersempit cakupan makna keputusan tersebut, yaitu : 1). Penetapan tertulis, 2). Dikeluarkan oleh Badan atau Jabatan (Pejabat) TUN, 3). Berisi Tindakan Hukum Tata Usaha Negara, 4). Bersifat Konkrit, 5). Indifidual, 6). Bersifat final, dan 7). Menimbulkan akibat hukum bagi seseorang atau badan hukum perdata.

Adapun UU Nomor 30 Tahun 2014 tentang Administrasi Pemerintahan, merumuskan Keputusan Tata Usaha Negara dengan makna yang lebih luas. Hal ini tercermin dari makna keputusan berdasarkan Pasal 1 angka 7 yaitu "ketetapan tertulis yang dikeluarkan oleh Badan dan/atau Pejabat Pemerintahan dalam penyelenggaraan pemerintahan". Rumusan tersebut hanya memuat beberapa unsur/batasan yaitu (1) penetapan tertulis, (2) dikeluarkan oleh pejabat pemerinatahn dan (3) dalam penyelenggaraan pemerintahan. Logikanya adalah dengan jumlah unsur-unsur yang sedikit berarti semakin luas cakupan atau makna dari keputusan tersebut, demikian pula sebaliknya.

Dengan pemaknaan yang lebih luas terhadap keputusan, berarti memperluas pula kewenangan PTUN dalam menangani sengketa-sengketa akibat adanya Keputusan Tata Usaha Negara yang dikeluarkan oleh Badan/Pejabat Pemerintahan. Dengan kata lain,

\footnotetext{
${ }^{6}$ http://ptun.jakarta.go.id, diakses Tanggal 23 Mai 2019
} 
kewenangan PTUN tidak lagi terbatas pada sengketa akibat keputusan dalam arti yang terbatas sebagaimana dimaksud dalam UU Peratun, tetapi mencakup keputusan yang lebih luas.

3. Kewenangan PTUN mengadili tindakan administrasi pemerintahan/tindakan faktual pejabat TUN.

Tindakan pemerintah dalam penyelenggaraan pemerintahan meliputi tindakan hukum (rechtelijke handelingen) maupun tindakan nyata/tindakan faktual (feitelijke handelingen). Selama ini objek sengketa tata usaha negara tidak mengenai objek sengketa tindakan faktual, sehingga perlu diakomodir dan dirumuskan sebagai objek sengketa tata usaha negara". 7

Dengan keluarnya UU Nomor 30 Tahun 2014, kewenangan PTUN tidak lagi hanya terhadap tindakan hukum pemeritah akibat penerbitan keputusan saja, tetapi juga juga terhadap tindakan faktual pemerintah yang dalam UU Nomor 30 Tahun 2014 dinamakan dengan istilah Tindakan Administrasi Pemerintahan. Sebagaimana tertera dalam Pasal 1 angka 8 yang menyatakan bahwa : "Tindakan Administrasi Pemerintahan yang disebut juga dengan Tindakan adalah perbuatan pejabat pemerintahan atau penyelenggara negara lainnya untuk melakukan dan/atau tidak melakukan perbuatan konkrit dalam rangka penyelenggaraan pemerintahan.

Adanya kewenangan PTUN terkait dengan tindakan administrasi pemerintahan ini tercermin dalam Pasal 75 ayat (1) jo Pasal 76 ayat (3) UU Nomor 30 Tahun 2014. Pasal 75 ayat (1) menyatakan bahwa : "Warga masyarakat yang dirugikan terhadap keputusan dan/atau tindakan dapat mengajukan upaya administratif kepada pejabat pemerintahan dan atau atasan pejabat yang menetapkan dan/atau melakukan keputusan dan/atau tindakan”. Selanjutnya Pasal 76 ayat (3) menyatakan bahwa : "Dalam hal warga masyarakat tidak menerima atas penyelesaian banding oleh atasan pejabat, warga masyarakat dapat mengajukan gugatan ke pengadilan". Adapun pengadilan yang dimaksud di sini dalam rumusan Ketentuan Umum pada Pasal 1 angka 18 UU Nomor 30 Tahun 2014 adalah PTUN.

\footnotetext{
${ }^{7}$ Priyatmanto Abdoellah, Revitalisasi Kewenangan PTUN Gagasan Perluasan Komptensi Peradilan Tata Usaha Negara, Cahaya Atma Pustaka, Yogyakarta, 2016, hal. 269
} 
Dengan demikian, sebagaimana dikemukakan oleh Laica Marzuki bahwa kompetensi Peradilan Tata Usaha Negara sehubungan dengan pemberlakuan UU Nomor 30 Tahun 2014 adalah memeriksa, mengadili dan memutus :

1. Perbuatan badan dan/atau Pejabat Pemerintahan dalam mengeluarkan Keputusan Administrasi Pemerintahan/KTUN (beschikkingsdaad).

2. Tindakan Pejabat Pemerintahan atau penyelenggara negara lainnya dalam melakukan dan/atau tidak melakukan perbuatan konkrit/faktual (materieele daad). ${ }^{8}$

Berdasarkan uraian di atas, terlihat bahwa UU Nomor 30 tahun 2014 memperluas kewenangan PTUN dengan pemberian kewenangan baru. PTUN tidak lagi hanya menangani perkara akibat tindakan hukum saja (keputusan tertulis) tetapi juga menangani perkara akibat tindakan faktuan/tindakan nyata pemerintahan.

Dari rumusan Pasal 75 ayat (1) dan Pasal 76 ayat (3) di atas, juga terlihat bahwa pihak pemohonnya disebutkan adalah warga masyarakat. Sebelumnya menurut UU Peratun pihak pemohonnya disebutkan terdiri dari orang/badan hukum perdata. Adapun yang dimaksud dengan warga masyarakat menurut Pasal 1 angka 15 UU Nomor 30 Tahun 2014 adalah seseorang atau badan hukum perdata yang terkait dengan keputusan dan/atau tindakan.

Adanya kewenangan mengadili tindakan pemerintahan ini tentunya berkorelasi terhadap kewenangan PTUN untuk memutus besarnya tuntutan ganti rugi tanpa batasan tertentu. Sebelumnya berdasarkan UU Peratun, tuntutan ganti rugi dimungkinkan sebagai tuntutan tambahan, namun besarnya tuntutan ganti rugi tersebut jumlahnya dibatasi dengan nilai nominal yang tergolong kecil. Berdasarkan Peraturan Pemerintah Nomor 43 Tahun 1991 tentang Ganti Rugi dan Cara Pelaksanaannya pada Peradilan Tata Usaha Negara, jumlahnya minimal Rp. 250.000,- (dua ratus lima puluh ribu rupiah) dan maksimal hanya Rp. 5.000.000,- (lima juta rupiah). Jumlah ini tentunya tidak sebanding dengan kemungkinan besarnya kerugian yang dialami pemohon.

Dengan adanya kewenangan PTUN terhadap tindakan nyata pemerintahan sebagaimana tercermin dalam Pasal 75 ayat (1) dan Pasal 76 ayat (3) UU Nomor 30 tahun 2014, dimungkinkan pula untuk mengajukan tuntutan ganti rugi sesuai kerugian yang dialami pemohon akibat tindakan faktual pejabat TUN.

\footnotetext{
${ }^{8}$ http://ptun.jakarta.go.id. Diakses Tanggal 23 Mei 2019
} 
4. Kewenangan PTUN dalam pengujian ada tidaknya penyalahggunaan wewenang oleh pejabat pemerintahan.

Kewenangan PTUN untuk melakukan pengujian ada atau tidaknya penyalahggunaan wewenang yang dilakukan oleh pejabat pemerintahan ini terdapat dalam Pasal 21 UU Nomor 30 Tahun 2014 sebagai berikut :

(1) Pengadilan berwenang menerima, memeriksa dan memutuskan ada atau tidak ada unsur penyalahgunaan wewenang yang dilakukan oleh pejabat pemerintahan.

(2) Badan dan/atau pejabat pemerintahan dapat mengajukan permohonan kepada pengadilan untuk menilai ada atau tidak ada unsur penyalahgunaan wewenang dalam keputusan dan/atau tindakan.

(3) Pengadilan wajib memutus permohonan sebagaimana dimaksud pada ayat (2) paling lama 21 (dua puluh satu) hari kerja sejak permohonan diajukan;

(4) Terhadap putusan pengadilan sebagaimana dimaksud pada ayat (3) dapat diajukan banding ke pengadilan tinggi tata usaha negara.

(5) Pengadilan tinggi tata usaha negara wajib memutus permohonan banding sebagaimana dimaksud pada ayat (4) paling lama 21 (dua puluh satu) hari kerja sejak permohonan banding diajukan.

(6) Putusan pengadilan tinggi tata usaha Negara sebagaimana dimaksu pada ayat (5) bersifat final dan mengikat.

Ketentuan di atas memberikan kewenangan yang sama sekali baru bagi PTUN untuk memeriksa ada tidaknya unsur penyalahgunaan wewenang dalam keputusan dan/atau tindakan pejabat pemerintahan. Dalam hal ini PTUN berwenang menerima, memeriksa dan memutuskan ada atau tidaknya unsur penyalahgunaan wewenang yang dilakukan oleh pejabat pemerintahan. Sebelumnya kewenangan menguji ada atau tidaknya unsur penyalahgunaan wewenang ini merupakan kewenangan dalam peradilan pidana.

Perluasan kewenangan tersebut sekaligus memperluas subjek dari pihak penggugat/pemohon ke PTUN. Sebelumnya berdasarkan UU Peratun yang menjadi pihak Pemohonnya adalah orang/badan hukum perdata yang merasa kepentingannnya dirugikan akibat dikeluarkannya keputusan tata usaha negara oleh badan/pejabat tata usaha negara, dan tergugatnya selalu dari pejabat pemerintahan. Sedangkan dari rumusan ayat (2) di atas, 
terlihat dengan jelas bahwa yang menjadi subjek pemohon pada pengujian ada atau tidak adanya unsur penyalahgunaan wewenang dalam keputusan dan/atau tindakan adalah Badan/Pejabat Pemerintahan.

5. Kewenangan Peradilan Tata Usaha Negara mengadili gugatan pasca upaya administrative (administratief beroep)

Upaya administrative ini merupakan salah satu kekhususan dalam hukum acara peratun. Menurut Indroharto upaya administratif merupakan prosedur yang ditentukan dalam suatu peraturan perundang-undangan untuk menyelesaikan suatu sengketa tata usaha negara yang dilaksanakan di lingkungan pemerintahan sendiri (bukan oleh badan peradilan) yang terdiri dari prosedur keberatan dan prosedur banding administratif. ${ }^{9}$

Upaya tersebut harus ditempuh (apabila tersedia) sebelum dilakukannya penyelesaian melalui peradilan TUN. Upaya ini dilakukan dengan cara mengajukan keberatan kepada badan/pejabat yang mengeluarkan keputusan. Apabila upaya keberatan tersebut belum membuahkan hasil maka langkah berikutnya adalah mengajukan banding administratif kepada atasan dari pejabat yang mengeluarkan keputusan.

Berdasarkan Pasal 48 UU Peratun, apabila semua prosedur upaya administratif yang tersedia telah ditempuh, tetapi tetap merasa tidak memuaskan, barulah dapat diajukan gugatan ke pengadilan, namun pengadilan yang dituju bukanlah PTUN tingkat Pertama melainkan adalah Pengadilan Tinggi Tata Usaha Negara (PT TUN). Hal ini sebenarnya sangat menyulitkan pemohon mengingat keberadaan PT TUN di Indonesia hingga saat ini masih terbatas, karena belum tersedia di semua wilayah propinsi sebagaimana yang diamanahkan dalam UU Peratun.

Melalui UU Nomor 30 Tahun 2014 kewenangan penyelesaian perkara pasca upaya administratif tersebut dilakukan oleh Pengadilan Tata Usaha Negara Tingkat Pertama. Hal ini tercermin dari Pasal 76 ayat (3) yang berbunyi bahwa :"Dalam hal warga masyarakat tidak menerima atas penyelesaian banding oleh atasan pejabat, warga masyarakat dapat mengajukan gugatan ke Pengadilan”. Pengadilan yang dimaksud dalam hal ini berdasarkan Pasal 1 angka 18 yaitu Pengadilan Tata Usaha Negara.

Ketentuan tersebut telah mengalihkan kewenangan mengadili gugatan setelah penyelesaian melalui upaya administratif dari PT TUN menjadi kewenangan PTUN

\footnotetext{
${ }_{9}^{9}$ Indroharto, Upaya Memahami Undang-Undang tentang Peradilan Tata Usaha Negara, Buku II Beracara di Pengadilan Tata Usaha Negara, Pustaka Sinar Harapan, Jakarta, 2003, hal.51
} 
Tingkat Pertama. Dengan adanya pengalihan tersebut sekaligus UU Nomor 30 Tahun 2014 ini telah memperluas kewenangan PTUN yaitu dalam hal mengadili perkara setelah upaya administratif. Peralihan ini tentunya dapat dikatakan lebih sejalan dengan tujuan dibentuknya PTUN yaitu memberikan perlindungan hukum kepada masyarakat. Sebab selama ini, dengan adanya loncatan penyelesaian perkara pasca upaya administratif langsung ke PT TUN mempersulit langkah masyarakat mendapatkan perlindungan hukum mengingat keberadaan PT TUN di Indonesia yang masih sangat terbatas karena belum tersedia di setiap wilayah propinsi sebagaimana dikehendaki oleh peraturan.

6. Kewenangan PTUN untuk memutuskan terhadap objek Keputusan Fiktif Positif.

Istilah keputusan fiktif positif didasarkan atas ketentuan Pasal 53 ayat (1), (2), (3) UU Nomor 30 Tahun 2014 yang menentukan batas waktu kewajiban bagi Badan dan/atau Pejabat Pemerintahan untuk menetapkan Keputusan dan/atau tindakan dalam rangka penyelenggaraan pemerintahan. Apabila ketentuan peraturan perundang-undangan tidak menentukan batas waktu kewajiban dimaksud, maka Badan dan/atau Pejabat pemerintahan wajib menetapkan dan/atau melakukan Keputusan dan/atau Tindakan dalam waktu paling lama 10 (sepuluh) hari kerja setelah permohonan diterima secara lengkap oleh Badan dan/atau Pejabat Pemerintahan. Apabila dalam batas waktu tersebut, Badan dan/atau Pejabat Pemerintahan tidak menetapkan Keputusan (KTUN) dan/atau Pejabat Pemerintahan tidak melakukan suatu tindakan konkret/faktual, maka permohonan tersebut dianggap dikabulkan secara hukum. Inilah yang kemudian dikenal dengan istilah Keputusan Fiktif Positif. Keputusan Fiktif Positif ini merupakan keputusan anggapan bahwa Badan dan/atau Pejabat Pemerintahan telah menerbitkan keputusan yang bersifat mengabulkan permohonan, dikarenakan tidak ditanggapinya permohonan yang diajukan oleh pemohon sampai dengan batas waktu yang ditentukan atau apabila tidak ditentukan telah lewat sepuluh hari setelah permohonan yang sudah lengkap diterima.

Terhadap Keputusan Fiktif Positif itu, Pasal 53 ayat (4), (5) dan (6) UU Nomor 30 Tahun 2014 memberi peluang kepada warga masyarakat mengajukan permohonan kepada PTUN untuk memperoleh Keputusan penerimaan permohonan tersebut. Dalam hal ini PTUN wajib memutuskan permohonan tersebut paling lama 21 hari kerja sejak permohonan diajukan. Kemudian Badan dan/atau Pejabat Pemerintahan wajib menetapkan Keputusan untuk melaksanakan putusan PTUN paling lama 5 (lima) hari kerja sejak putusan pengadilan ditetapkan. 
Berdasarkan hal tersebut jelaslah bahwa UU Nomor 30 Tahun 2014 menentukan adanya kewenangan PTUN untuk memutuskan mengenai penerimaan permohonan yang diajukan pemohon. Ketentuan tentang Keputusan Fiktif Positif berbeda dengan istilah Keputusan Fiktif Negatif yang dianut sebelumnya dalam Pasal 3 UU Peratun yang telah dijelaskan sebelumnya.

Diadopsinya konsep Keputusan Fiktif Positif dalam UU Nomor 30 tahun 2014 menurut Laica Marzuki tidak dengan seketika menyampingkan pemberlakuan Keputusan Fiktif Negatif menurut Pasal 3 UU Nomor 5 tahun 1986 tentang PTUN, yang menganggap Badan dan/atau Pejabat Tata Usaha Negara telah menolak mengeluarkan suatu KTUN manakala dalam batas waktu tertentu tidak mengeluarkan keputusan yang dimohonkan. UU Nomor 30 Tahun 2014 tidak menyampingkan atau membatalkan Pasal 3 UU Nomor 5 tahun 1986. Hal dimaksud tergantung sejauhmana Pasal 3 UU Nomor 5 Tahun 1986 masih merupakan kebutuhan hukum bagi pencari keadilan (justiciable) dalam praktek upaya hukum administrasi. Lagi pula, Pasal 3 UU Nomor 5 tahun 1986 berkenaan dengan Keputusan Fiktif Negatif tidak dapat diterapkan bagi pengajuan permohonan dilakukannya (= atau tidak dilakukannya) Tindakan Konkret/Faktual dari pejabat pemerintahan. Beranjak dari uraian di atas, terlihat bahwa terdapat perluasan kewenangan PTUN untuk memutuskan terhadap objek Keputusan Fiktif Positif, di samping masih adanya kewenangan menangani perkara atas keputusan fiktif negative.

7. Implementasi Perluasan Kewenangan PTUN Berdasarkan UU Nomor 30 Tahun 2014 tentang Administrasi Pemerintahan di PTUN Jambi.

Implementasi perluasan kewenangan PTUN berdasarkan Undang-Undang Nomor 30 Tahun 2014 di PTUN Jambi dapat dilihat dari perkara-perkara yang ditangani sejak undang-undang ini berlaku efektif sejak diundangkan Tanggal 17 Oktober 2014 hingga sekarang telah berjalan selama hampir 5 (lima) tahun.

Berdasarkan informasi yang diperleh dari responden di PTUN Jambi diketahui bahwa sejak berlakunya UU Nomor 30 Tahun 2014 tentang Administrasi Pemerintahan, PTUN Jambi telah menangani beberapa permohonan yang merupakan kewenangan baru PTUN yang ada sejak diundangkannya UU Nomor 30 Tahun 2014 tersebut. Sehubungan dengan itu penulis melihatnya dari gambaran perkara yang ditangani oleh PTUN Jambi mulai Tahun 2015 sebagaimana tertera pada tabel-tabel berikut : 
Tabel 1 : Jenis-Jenis Perkara yang ditangani PTUN Jambi Tahun 2015

\begin{tabular}{|l|l|c|c|c|c|c|}
\hline No & Jenis Perkara & Sisa Tahun lalu & Masuk & Cabut & Putus & Sisa \\
\hline 1. & Pertanahan & 1 & 3 & - & 3 & 1 \\
\hline 2. & Kepegawaian & - & 5 & 1 & 3 & 1 \\
\hline 3. & Perizinan & 4 & 3 & - & 7 & - \\
\hline 4. & Lain-lain & - & 3 & & 1 & 2 \\
\hline & Jumlah & 5 & 14 & 1 & 14 & 4 \\
\hline
\end{tabular}

Sumber : Pengadilan Tata Usaha Negara Jambi

Berdasarkan tabel 1 di atas, terlihat bahwa selama Tahun 2015 terdapat 4 jenis perkara yang ditangani PTUN Jambi, meliputi perkara di bidang pertanahan, kepegawaian, perizinan dan perkara lain-lain. Perkara bidang pertanahan, kepegawaian dan perizinantersebut termasuk dalam kategori perkara yang menjadi kewenangan PTUN berdasarkan UU Peratun. Sedangkan jenis perkara lain-lain mengindikasikan adanya jenis perkara yang terkait dengan keputusan tata usaha negara dalam arti yang lebih luas sebagaimana dimaknai dalam UU Nomor 30 tahun 2014. Hal ini mengindikasikan bahwa implementasi perluasan kewenangan PTUN Jambi pada Tahun 2015 baru terkait dengan perluasan cakupan keputusan yang disengketakan.

Selanjutnya dari gambaran perkara-perkara yang diselesaikan PTUN Jambi selama Tahun 2016 dapat dilihat pada tabel berikut :

Tabel 2: Jenis-jenis Perkara yang Ditangani PTUN Jambi Tahun 2016

\begin{tabular}{|l|l|c|c|c|c|c|}
\hline No & Jenis Perkara & Sisa Tahun lalu & Masuk & Cabut & Putus & Sisa \\
\hline 1. & Pertanahan & 1 & 4 & - & 3 & 2 \\
\hline 2. & Kepegawaian & 1 & 6 & 1 & 5 & 1 \\
\hline 3. & Perizinan & - & 1 & - & - & 1 \\
\hline 4. & Pemilukada & - & 1 & - & 1 & - \\
\hline 5. & Lain-lain & 2 & 18 & 5 & 13 & 2 \\
\hline 6. & $\begin{array}{l}\text { Permohonan } \\
\text { Fiktif Positif }\end{array}$ & - & 4 & 1 & 3 & - \\
\hline & Jumlah & 4 & 34 & 7 & 25 & 6 \\
\hline
\end{tabular}

Sumber data : Peradilan Tata Usaha Negara Jambi

Berdasarkan tabel 2 di atas, ada 6 (enam) jenis perkara yang ditangani PTUN Jambi selama Tahun 2016. Perkara-perkara tersebut terdiri dari perkara-perkara bidang pertanahan, kepegawaian, perizinan, pemilukada, lain-lain, dan perkara fiktif positif. 
Implemenatsi perluasan kewenangan terlihat pada penanganan jenis perkara lain-lain yang terlihat paling banyak, juga terlihat adanya perkara yang merupakan kewenangan baru PTUN yaitu pada penanganan perkara permohonan fiktif positif yang berjumlah 4 (empat) perkara.

Telah dikemukakan sebelumnya bahwa permohonan fiktif positif ini merupakan jenis permohonan terkait adanya permohonan yang diajukan oleh seseorang/badan hukum perdata kepada badan dan/atau pejabat pemerintahan untuk menetapkan dan/atau melakukan keputusan dan/atau tindakan, namun badan dan /atau pejabat pemerintahan tidak menanggapi permohonan tersebut sampai batas waktu yang telah ditetapkan oleh peraturan perundang-undangan, maka dalam hal ini badan dan/atau pejabat pemerintahan dianggap telah mengabulkan permohonan pemohon. Untuk itu itu, pemohon mengajukan permohonan kepada PTUN Jambi agar badan dan/atau pejabat pemerintahan mengeluarkan Keputusan penerimaan permohonan tersebut. Dari tabel di atas terlihat bahwa pada tahun 2016 terdapat 4 (empat) jenis perkara permohonan fiktif positif yang masuk ke PTUN, 3 (tiga) dari perkara tersebut telah diputus sedangkan 1 (satu) diantaranya dicabut.

Berikutnya adalah uraian perkara yang masuk dan diselesaikan PTUN Jambi pada Tahun 2017 sebagaimana tertera pada tabel berikut :

Tabel 3: Jenis-Jenis Perkara yang Ditangani PTUN Jambi Tahun 2017

\begin{tabular}{|l|l|c|c|c|c|}
\hline No & Jenis Perkara & Sisa Tahun lalu & Masuk & Putus & Sisa \\
\hline 1. & Pertanahan & 2 & 10 & 8 & 4 \\
\hline 2. & Kepegawaian & 1 & 6 & 6 & 1 \\
\hline 3. & Perizinan & 1 & 2 & 1 & 2 \\
\hline 4. & Lelang & - & - & 1 & - \\
\hline 5. & Lain-lain & - & 4 & 3 & 3 \\
\hline 6. & Permohonan Fiktif & & 2 & 1 & 1 \\
\hline 7. & Positif & & & & \\
\hline & Jumgujian penyalahgunaan & - & 2 & 1 & 1 \\
\hline
\end{tabular}

Sumber data : Peradilan Tata Usaha Negara Jambi.

Berdasarkan tabel 3 di atas terlihat ada 7 (tujuh) jenis perkara yang ditangani PTUN Jambi Tahun 2017, terdiri dari perkara-perkara bidang pertanahan, kepegawaian, 
perizinan, lelang, perkara lain-lain, perkara fiktif positif serta perkara pengujian penyalahgunaan wewenang. Dari jenis-jenis perkara tersebut, implementasi perluasan kewenangan terlihat pada penanganan perkara lain-lain sebanyak 6 perkara, perkara permohonan fiktif positif sebanyak 2 (dua) perkara dan perkara permohonan pengujian ada tidaknya penyalahgunaan wewenang sebanyak 2 (dua) perkara. Dari dua permohonan fiktif positif tersebut, satu permohonan telah diputuskan oleh PTUN Jambi, begitu juga dari dua permohonan pengujian penyalahgunaan wewenang juga telah diputuskan PTUN Jambi 1 (satu) permohonan. Hal ini menunjukkan bahwa Tahun 2017 implementasi perluasan kewenangan PTUN mulai meningkat.

Adapun pengujian penyalahgunaan wewenang ini merupakan kewenangan PTUN untuk menerima, memeriksa dan memutus permohonan penilaian ada atau tidak ada penyalahgunaan wewenang dalam Keputusan dan/atau Tindakan Pejabat Pemerintahan sebelum adanya proses pidana. Dalam hal ini pengadilan baru berwenang menerima, memeriksa dan memutus penilaian permohonan tersebut setelah adanya hasil pengawasan aparat pengawasan intern pemerintah.

Selanjutnya dari perkara-perkara yang masuk dan diselesaikan PTUN Jambi Tahun 2018 dapat dilihat pada Tabel berikut :

Tabel 4: Jenis-Jenis Perkara yang ditangani PTUN Jambi Tahun 2018.

\begin{tabular}{|c|l|c|c|c|c|c|c|c|}
\hline $\begin{array}{c}\text { N } \\
\text { o }\end{array}$ & Jenis Perkara & $\begin{array}{c}\text { Sisa } \\
\text { Tahun } \\
\text { lalu }\end{array}$ & $\begin{array}{c}\text { Masu } \\
\mathrm{k}\end{array}$ & $\begin{array}{c}\text { Dismissa } \\
1\end{array}$ & $\begin{array}{c}\text { Perlawana } \\
\mathrm{n}\end{array}$ & $\begin{array}{c}\text { Cab } \\
\text { ut }\end{array}$ & $\begin{array}{c}\text { Putu } \\
\text { s }\end{array}$ & Sisa \\
\hline 1. & Pertanahan & 4 & 6 & - & - & - & 10 & - \\
\hline 2. & Kepegawaian & 1 & 22 & - & - & - & 16 & 7 \\
\hline 3. & Pajak & & 4 & 2 & 2 & - & 2 & - \\
\hline 4. & Perizinan & 2 & 4 & - & - & - & 4 & 2 \\
\hline 5. & Pemilukada & & 1 & 1 & - & - & - & - \\
\hline 6. & Lain-lain & 3 & 10 & - & - & 2 & 8 & 3 \\
\hline 7. & KIP & - & 1 & - & - & - & 1 & - \\
\hline 8. & $\begin{array}{l}\text { Permohonan } \\
1\end{array}$ & 3 & - & - & 2 & 2 & 1 \\
\hline 9. & Pengujian & & & & - & - & & - \\
\hline
\end{tabular}




\begin{tabular}{|l|l|l|l|l|l|l|l|l|}
\hline & an wewenang & & & & & & & \\
\hline & Jumlah & 12 & 51 & 3 & 2 & 4 & 44 & 12 \\
\hline
\end{tabular}

Dari tabel di atas terlihat ada 9 (sembilan) jenis perkara yang ditangani PTUN selama Tahun 2018, terdiri dari perkara bidang pertanahan, kepegawaian, pajak, perizinan, pemilukada, lain-lain, Keterbukaan Informasi Publik (KIP), permohonan fiktif positif dan permohonan penyalahgunaan wewenang. Dari jenis-jenis perkara tersebut, implementasi perluasan kewenangan PTUN Jambi juga terlihat dari banyaknya jenis perkara lain-lain, permohonan keputusan fiktif positif sebanyak 4 perkara dan 1 (satu) perkara pengujian penyalahgunaan wewenang oleh pejabat pemerintahan.

Sementara untuk Tahun 2019 yang masih sedang berjalan, berdasarkan data yang penulis peroleh diketahui bahwa sampai dengan bulan Juli 2019 baru ada 3 jenis perkara yang diproses PTUN Jambi, yaitu perkara di bidang pertanahan, kepegawaian, dan perizinan. Artinya belum ada kewenangan baru terkait kewenangan yang diatur dalam UU Nomor 30 Tahun 2014 yang masuk ke PTUN.

Berdasarkan uraian di atas diketahui bahwa sejak tahun 2015 hingga bulan Juni Tahun 2019 telah ada implementasi perluasan kewenangan baru PTUN berdasarkan UU Nomor 30 Tahun 2014, yaitu kewenangan memutus perkara fiktif positif dan kewenangan pengujian ada tidaknya penyalahgunaan wewenang yang dilakukan oleh pejabat pemerintahan. Hingga bulan Juni 2019 permohonan perkara fiktif positif yang ditangani PTUN Jambi sebanyak 9 (sembilan) perkara, sedangkan pengujian ada tidaknya penyalahgunaan wewenang, baru ada sebanyak 2 perkara.

Sementara kewenangan baru PTUN terkait dengan pengujian terhadap tindakan faktual pejabat pemerintahan belum terlihat implementasinya pada perkara yang ditangani PTUN Jambi. Hal tersebut dipertegas oleh Rusianto selaku Panitera Pengganti pada PTUN Jambi mengungkapkan bahwa hingga pertengahan Tahun 2019 belum pernah ada pengajuan permohonan untuk pengujian terhadap tindakan faktual pemerintah. Hal ini dapat dimaklumi, masyarakat mungkin belum memahaminya karena selama ini kewenangan tersebut merupakan kewenangan peradilan umum.

Adapun implementasi perluasan kewenangan PTUN terkait dengan perluasan cakupan atau makna Keputusan yang dapat menjadi objek sengketa di PTUN tergambar dari banyaknya jenis perkara lain-lain yang ditangani PTUN sebagaimana tertera pada tabel 1 hingga table 4 yang keseluruhannya berjumlah 35 perkara. Hal ini mengindikasikan 
telah banyaknya permohonan yang ditangani PTUN Jambi terkait adanya perluasan cakupan makna keputusan yang dapat menjadi objek sengketa di PTUN, sehingga hakim PTUN tidak lagi terbatas pada menangani perkara terkait pada keputusan tertentu berupa penetapan tertulis yang bersifat konkrit, indifidual dan final sebagaimana diatur dalam UU Peratun. Dengan perluasan makna keputusan menurut UU Administrasi Pemerintahan, sepanjang keputusan tersebut bermakna sebagai keputusan tertulis yang dikeluarkan oleh pejabat pemerintahan dalam menyelenggarakan pemerintahan, maka telah cukup menjadi objek sengketa di PTUN apabila keputusan tersebut bertentangan dengan hukum dan merugikan warga masyarakat.

\section{E. Kesimpulan \& Saran}

1. Kesimpulan

Berdasarkan pembahasan yang telah dikemukakan pada bab sebelumnya, maka dapat disimpulkan bahwa :

1. Perluasan kewenangan Peradilan Tata Usaha Negara berdasarkan Undang-Undang Nomor 30 Tahun 2014 tentang Administrasi Pemerintahan terkait dengan adanya :

a. Perluasan pemaknaan keputusan yang menjadi objek sengketa. Dengan adanya perluasan pemaknaan terhadap keputusan tata usaha negara berimplikasi terhadap perluasan kewenangan PTUN yang semula hanya berwenang menangani sengketa terkait dengan keputusan tata usaha negara tertentu (berupa penetapan tertulis yang bersifat konkrit, individual dan final serta menimbulkan akibat hukum bagi seseorang atau badan hukum perdata), setelah keluarnya UU Nomor 30 Tahun 2014 PTUN mempunyai kewenangan menangani sengketa terkait dengan keputusan tata usaha negara yang lebih luas (berupa penetapan tertulis yang dikeluarkan pemerintah dalam penyelenggaraan pemerintahan).

b. Peralihan kewenangan mengadili sengketa pasca upaya administratif dari kewenangan PT TUN menjadi kewenangan PTUN.

c. Penambahan beberapa kewenangan baru PTUN, yaitu kewenangan mengadili tindakan faktual pemerintahan, pengujian ada tidaknya penyalahgunaan wewenang oleh pemerintahan serta kewenangan memutus terhadap keputusan fiktif positif. 
2. Impelementasi perluasan kewenangan PTUN berdasarkan UU Nomor 30 Tahun 2014 pada PTUN Jambi telah terlihat dari jenis-jenis perkara yang ditangani PTUN sejak diberlakukannya UU Nomor 30 tahun 2014, yang tidak lagi hanya menangani perkara terkait dengan objek keputusan tata usaha negara tertentu berdasarkan UU Peratun. Selain telah menangani perkara terkait keputusan tata usaha negara yang lebih luas, juga sudah terlihat adanya implementasi kewenangan baru PTUN yaitu kewenangan memutus permohonan fiktif positif dan kewenangan pengujian ada tidaknya penyalahgunaan wewenang oleh pejabat pemerintahan. Sementara implementasi kewenangan mengadili tindakan faktual pejabat pemerintahan belum terlihat sama sekali.

2. Saran

1. Perlu adanya upaya dari PTUN Jambi untuk ikut mensosialisasikan perluasan kewenangan PTUN agar dapat diketahui oleh masyarakat luas terutama adanya kewenangan PTUN untuk mengadili sengketa akibat tindakan faktual pejabat pemerintahan di lingkungan provinsi Jambi, misalnya melalui spanduk atau pamplet yang dipasang pada tempat-tempat yang mudah terlihat dan dibaca masyarakat yang berkunjung ke PTUN Jambi.

2. Perluasan kewenangan PTUN berdasarkan UU Nomor 30 Tahun 2014 perlu disikapi oleh PTUN Jambi dengan mempersiapkan langkah-langkah guna mewujudkan fungsi PTUN dalam memberikan perlindungan bagi masyarakat dari sikap tindak tindak pemerintah yang merugikan dengan tetap mengedepankan azas peradilan cepat dan biaya ringan.

\section{F. Daftar Pustaka}

Aminuddin Ilmar, Hukum Tata Pemerintahan, Prenada Media Group, Jakarta, 2014.

Indroharto, Upaya Memahami Undang-Undang tentang Peradilan Tata Usaha Negara, Buku I Beracara di Pengadilan Tata Usaha Negara, Pustaka Sinar Harapan, Jakarta, 2000.

, Upaya Memahami Undang-Undang tentang Peradilan Tata Usaha Negara, Buku II Beracara di Pengadilan Tata Usaha Negara, Pustaka Sinar Harapan, Jakarta, 2003

Marbun, Hukum Administrasi Negara I, FH UII Press, Yogyakarta, 2012.

Priyatmanto Abdoellah, Revitalisasi Kewenangan PTUN, Cahaya Atma Pustaka, Yogyakarta, 2016

Ridwan HR, Hukum Administrasi Negara, PT. RajaGrafindo Persada, Jakarta, 2007. 
Rozali Abdullah, Hukum Acara Peradilan Tata Usaha Negara, Rajawali Pers, Jakarta, 1992.

Suratman dan Philips Dillah, Metode Penelitian Hukum, Alfabeta.Malang,2014 